\title{
Baboon Cake (Traditional Indonesian Cake) as an Alternative Food of Low Glychemic Index
}

\author{
Sefanadia Putri $^{1 *} \quad$ Arie Nugroho ${ }^{1} \quad$ Siti Nurdjanah $^{2}$ \\ 1.Tanjungkarang Health Polytechnic, Province Lampung, Indonesian \\ 2.University of Lampung, Province Lampung, Indonesian
}

\begin{abstract}
Development of baboon cake can be using local food sources. This research will be study the characterization of traditional Lampung cake (baboon) substituted prebiotics from modified red sweet potato flour and tempeh flour as an alternative to low glycemic index snack. The method used in this study was a completely randomized design (CRD) with 2 treatments and five replications. The treatments in this study were the differences in the basic ingredients formula for baboon cake control: K1 (100\% tapioca) and K2 (60\% tapioca, 20\% tempeh flour, 20\% sweet potato flour modification). Analysis data for resistant starch, dietary fiber, digestible starch and the glycemic index were analyzed using Independent sample T-test. There are significant differences in digestible starch, dietary fiber resistant starch and glycemic index of the control baboon cakes and the baboon cakes K2. Control baboon cake (K1) has digestible starch of $20,02 \%$, resistant starch of $13.39 \%$, dietary fiber of $21,58 \%$. The baboon cake (K2) has digestible starch of $15,97 \%$, resistant starch of $27.94 \%$ and dietary fiber of $37,74 \%$. The control baboon cake has a Glycemic Index of 61.67 and a Glycemic load of 12.88 including the "medium" category and baboon cake $\mathrm{K} 2$, which is a substitution of modified sweet potato flour and tempeh flour has a GI of 46.77 and a glycemic load amounted to 5.21 with the "low" category.
\end{abstract}

Keywords: Baboon cake, glycemix indeks, prebiotic

DOI: $10.7176 / \mathrm{FSQM} / 106-05$

Publication date:March $31^{\text {st }} 2021$

\section{Introduction}

The problem of non-communicable disease (NCD) such as obesity is still a serious problem in Indonesia where the obesity rate in Indonesia is also quite high. The increasing of obesity will affect the increase of NonCommunicable Diseases (NCD), like diabetes. Treatment for people with type 2 diabetes mellitus needs to be given diet therapy in the form of a low glycemic index diet. Foods with a low glycemic index experience a slow digestion process, so the rate of stomach emptying is slow. This causes the food suspension to reach the small intestine more slowly, so that glucose absorption in the small intestine is slow (Hoerudin, 2012).

The concept of the Glycemic Index (GI) is an approach to choosing good food, especially food sources of carbohydrates. Indonesia has a variety of food ingredients that are very good for consumption. One of the traditional foods of Lampung, a type of cookies, is baboon cake. Baboon cakes are generally made using tapioca as a base. Baboon cake development which is one of the typical Lampung foods can be done by utilizing existing local food sources. Baboon cakes can be used as functional food if they have functional properties for health, including controlling blood glucose levels and having a low glycemic index. These functional properties can be obtained through changes to the main ingredient, namely reducing the use of tapioca with other food ingredients that have higher fiber content and relatively low GI (Kustanti, 2017).

Based on research data from (Putri and Muliani, 2019), modified red sweet potato flour contains $19.75 \%$ resistant starch with a total dietary fiber (TDF) of $44.64 \%$. Resistant starch has the advantage of being a prebiotic when compared to FOS and inulin because it is able to bind and maintain water content in feces, so it does not cause constipation and flatulence if consumed in large quantities (Vatanasuchart, Niyomwit and Wongkrajang, 2012). The high content of undigested carbohydrates such as dietary fiber and resistant starch in modified sweet potato flour allows it to be developed as a prebiotic source of food. Prebiotics also contribute to weight loss, body fat, and fat cell size by regulating the intake of food used by the body (Neyrinck et al., 2011).

An alternative to increasing the nutritional value (protein) of baboon cake processing products is the addition of tempeh flour. Tempeh contains complete essential and non-essential amino acids, low levels of saturated fat, high isoflavones, high fiber, low GI (glycemic index <55), and easy to digest (a). Based on The advantages of modified sweet potato flour and tempeh flour can be used as safe and healthy alternative food ingredients for diabetes mellitus sufferers.

These food ingredients can be used as an internal substitution material making food products in the form of baboon cakes so that the province of Lampung has superior products that have high economic value, are attractive and can compete in the market as well as are safe and healthy. Therefore, this research will study the characterization of traditional Lampung cakes (baboon) substituted prebiotics from modified red sweet potato flour and tempeh flour as an alternative to a low glycemic index snack. The purpose of this study was to determine dietary fiber, resistant starch, digestible stach, glycemic index and glycemic load of traditional Lampung cakes 
(baboon) prebiotic substitution of modified red sweet potato flour and tempeh flour.

\section{Materials and Methods}

Preparation of Baboon cookies

The first preparation is Modified Sweet Potato (Mosep) Red Flour (IPR certificate : 000179513). The raw material were red sweet potato from Province Lampung Indonesian. Mosep red flour was prepared by the autoclaving retrogradation method based on (Putri and Muliani, 2019). Preparation of tempeh flour method based on (Bastian et al., 2013).

Production of Baboon Cookies were done through the following stages: blondo preparation (Cooking pure coconut milk that has been added with water, lime leaves, pandan leaves and salt. Cook over medium heat $\left(70^{\circ} \mathrm{C}\right.$ \pm 30 minutes) until blondo (coconut milk becomes a solid lump), dough beating, mixing, forming and roasting the dough.

\section{Materials and Tools}

The materials used in this research were $170 \mathrm{ml}$ coconut milk, $100 \mathrm{ml}$ water, $150 \mathrm{~g}$ tapioca, $50 \mathrm{~g}$ mosep red flour, $50 \mathrm{~g}$ tempeh flour, $50 \mathrm{~g}$ wheat flour, $50 \mathrm{~g}$ sugar, $50 \mathrm{~g}$ brown sugar, $50 \mathrm{~g}$ egg, $50 \mathrm{~g}$ margarin. The chemical materials used for analysis include distilled water, $\mathrm{HCl}, \mathrm{NaOH}$, phosphate buffer, pepsin, ethanol, methanol, pepsin, alpha amylase enzyme (NOVO brand) and amyloglucosidase enzyme (NOVO brand), alcohol, petroleum ether, acetone, acid. ascorbate, aluminum foil, and DPPH (Sigma Aldrich) and other chemicals. The tools used in this study were analytical scales, knives, basin, SLEVA equitron type autoclave, freezer, 80 mesh sieve, drying oven.

\section{Analysis of Functional Component}

Analysis of functional component, included: dietary fiber by enzymatic method (AOAC Official Method 2011.25 in (Mccleary, 2012), resistant starch (RS) by modifying the developed method (Goñi et al., 1996) and digestible starch (DS) based on (Muchtadi, Palupi and M, 1992).

\section{Analysis of The Glycemic Index Value}

The tests of glycemic index were carried out on ten healthy volunteers, i.e. non-diabetic, have the normal level of fasting blood glucose $(70-120 \mathrm{mg} / \mathrm{dl})$ and value of Body Mass Index (BMI) in the normal range of 18.5 to 25 $\mathrm{kg} / \mathrm{m} 2$. The tests were conducted based on the ethical clearance issued by the Tanjung Karang Health Polytechnic with number No. 271/KEPK-TJK/VI/2020. The GI, was calculated following the procedure of regulations Head of the Food and Drug Administration (Badan Pengawasan Obat dan Makanan, 2011).

\section{Data Analysis}

The method used in this study was a completely randomized design (CRD) with two treatments and five replications. The treatment in this study was the difference in the composition of the basic ingredients of baboon cake: K1 (100\% tapioca) dan K2 (60\% tapioca, 20\% tempeh flour, 20\% sweet potato flour modification. Analyzed data for resistant starch, dietary fiber, digestible starch, glycemic index and glycemic load were using the Independent sample T-test.

\section{Results and Discussion}

\section{Functional Component}

The results analysis of functional component, included: dietary fiber, resistant starch (RS) and digestible starch (DS) in prebiotic substituted baboon cake products from modified red sweet potato flour and tempeh flour can be seen in Table 1.

Table 1. Functional Component of baboon cakes

\begin{tabular}{|l|l|l|l|}
\hline Variabel & Resistant starch (\%) & dietary fiber (\%) & Digestible starch (\%) \\
\hline Baboon cake control (K1) & 13,39 & 21,58 & 20,02 \\
\hline Baboon cake (K2) & 27,94 & 37,74 & 15,97 \\
\hline P-Value & 0,001 & 0,001 & 0,002 \\
\hline
\end{tabular}

*Independent T-test

For each parameter (column), values with the same letters are not significantly different $(\mathrm{P}>0.05)$.

The content of resistant starch, dietary fiber and digestible starch has been positively correlated in the prebiotic substitution of modified red sweet potato flour and tempeh flour of control baboon cakes and the (K2) baboon cakes. Analysis of resistant starch and dietary fiber baboon cakes for the highest average score is baboon cake (K2), respectively $27.94 \%$ and $37.74 \%$, while the lowest average score (control) was for resistant starch and dietary fiber respectively of $13.39 \%$ and $21.58 \%$. The lower of DS content is due to the increasing of RS content (Table 1). Resistant starch is a type of starch that is not digested (resistant) in the human digestive system. Resistant starch in food ingredients is divided into five groups, among others; (a) very low (<1\%), (b) low (1-2.5\%), (c) 
moderate $(2.5-5 \%)$, (d) high (5-15\%) and (e) very high (> 15\%) (Goni et al., 1996; Birt et al., 2013. The baboon cake $(\mathrm{K} 2)$ is (tapioca: modified red sweet potato flour: tempeh flour $=60: 20: 20) \%$ has a food fiber content of $37.74 \%$ and resistant starch is $27.94 \%$ with category of very high. Statistical test results showed that the substitution of modified red sweet potato flour and tempeh flour significantly differed in the levels of resistant starch and food fiber of control baboon cakes and K2. Dietary fiber in the baboon cake (K2) is due to the modification of the substitution of modified red sweet potato flour and tempeh flour.

Based on research data from (Putri and Muliani, 2019), modified red sweet potato flour has a high content of dietary fiber, namely $44.64 \%$ consisting of $25.46 \%$ insoluble food fiber and $19.18 \%$ soluble food fiber, therefore sweet potato flour modified red is very good for digestion. Resistant starch on baboon cake K2 has been dominated by RS 3 as a result of retrogradation. Retrogradation will increase crystallinity degree of starch (Alsaffar, 2011). Hydrolysis of resistant starch by digestive enzymes generally takes a slower time, so consuming resistant starch can lower blood sugar content. This is caused by resistant starch which produces energy in a fairly slow process, so that it is not immediately absorbed in the form of glucose. In addition, according to (Keenan et al., 2015) the presence of resistant starch also increases the presence of GLP-1 (glucagon like peptide 1), where this GLP-1 stimulates insulin formation. Resistant starch also has an effect that can reduce glycemic and insulin responses, lower cholesterol, and a protective effect against colon cancer through a microflora process which is able to convert resistant starch into short chain fatty acids ((Aparicio-Saguilán et al., 2007). Therefore it is expected that with the high resistant starch in baboon cakes, the glycemic index value of the food is low. Based on the lower of DS content, Baboon cake K2 has potency as functional food. Food with lower DS has potential as functional food to improve human health (Ai, 2013).

\section{Glycemic Index (GI) and Glycemic Load (BG)}

a. Subject Characteristics

Subjects consisted of 10 volunteers who had signed informed consent with normal nutritional status (BMI 18.5 $22.9 \mathrm{~kg} / \mathrm{m} 2$ ) and fasting blood glucose between $70-120 \mathrm{mg} / \mathrm{dl}$, and ages ranging from 21 years. Characteristics of the research subjects can be seen in Table 2. Based on the table, it is known that the average age of the subjects is 21 years with an average BMI of $20.33(\mathrm{~kg} / \mathrm{m} 2)$ and Fasting Blood Sugar (FBS) $77.3 \mathrm{mg} / \mathrm{dl}$. This is in accordance with the subject's inclusion criteria. Characteristics of the Subjects can be seen of Table 2.

Table 2. Characteristics of the Subjects

\begin{tabular}{|l|l|l|l|l|l|}
\hline Subject & Age (Year) & Weight $(\mathrm{kg})$ & Height $(\mathrm{cm})$ & BMI $(\mathrm{kg} / \mathrm{m} 2)$ & FBS $(\mathrm{mg} / \mathrm{dl})$ \\
\hline 1 & 21 & 57 & 157 & 23,12 & 80 \\
\hline 2 & 21 & 46,5 & 158 & 18,63 & 80 \\
\hline 3 & 21 & 48 & 157 & 19,47 & 85 \\
\hline 4 & 21 & 57 & 156 & 23,42 & 82 \\
\hline 5 & 21 & 49 & 156 & 20,13 & 72 \\
\hline 6 & 21 & 53 & 165 & 19,47 & 70 \\
\hline 7 & 21 & 55 & 162 & 20,96 & 70 \\
\hline 8 & 21 & 45 & 157 & 18,26 & 82 \\
\hline 9 & 21 & 52 & 157 & 21,10 & 78 \\
\hline 10 & 21 & 45 & 155 & 18,73 & 74 \\
\hline Average & 21 & 50,75 & 158 & 20,33 & 77,3 \\
\hline
\end{tabular}

b. Determination amount of sample food

Nutritional facts assessed for its glycemic index are formula 2 baboon cake with the ratio of tapioca : modified sweet potato flour: tempeh flour = 60:20: 20, while the standard food used in this study is obtained in ready to eat. Results analysis of nutrient facts per $100 \mathrm{~g}$ can be seen in Table 3.

Table 3. Nutrient facts per $100 \mathrm{~g}$

\begin{tabular}{|l|l|l|l|l|l|l|}
\hline \multirow{2}{*}{ Sample Food } & \multicolumn{6}{|c|}{ nutritional facts(\%) } \\
\cline { 2 - 7 } & Water & Ash & Protein & Fat & Fiber & Carbohydrate \\
\hline Bread * & - & - & 8,88 & 4,44 & 4,44 & 50,6 \\
\hline Baboon cake control (K1) & 5,49 & 0,98 & 3,39 & 15,01 & 0,66 & 74,46 \\
\hline Baboon cake (K2) & 6,82 & 1,23 & 6,18 & 17,02 & 1,07 & 67,66 \\
\hline
\end{tabular}

* white bread merk of sari roti, double soft type

c. Response of Blood Glucose

The average results of the subject's blood glucose response to the provision of bread, control baboon cake and formula 2 baboon cake can be seen in Table 4 . 
Tabel 4. Average Blood Glucose Response (mg/dl)

\begin{tabular}{|l|r|r|r|r|r|}
\hline \multirow{2}{*}{ Sample Food } & \multicolumn{6}{|c|}{ Time (minute) } \\
\cline { 2 - 6 } & \multicolumn{1}{|c|}{0} & \multicolumn{1}{c|}{30} & \multicolumn{1}{c|}{60} & \multicolumn{1}{c|}{120} \\
\hline Bread & 77,3 & 108,3 & 107,3 & 111,1 & 96,2 \\
\hline Baboon cake control (K1) & 79,2 & 102 & 100,8 & 98 & 95,5 \\
\hline Baboon cake (K2) & 82,4 & 102,1 & 93,4 & 89,7 & 80,3 \\
\hline
\end{tabular}

Based on Table 4 it is known that the peak of the increase in blood sugar levels for bread occurs at 30 minutes after eating and decreases gradually in the following minutes. More details on the percentage value of increase or decrease can be seen in Table 5. In Table 5 A sign $(+)$ or no sign indicates a large increase in blood glucose levels while a sign (-) indicates a large decrease. All values are in $\mathrm{mg} / \mathrm{dl}$. When compared with the provision of plain bread, the increase in blood glucose levels in the control and baboon cakes (K2) occurred at 30 minutes.

Table 5. Increase / decrease in blood glucose

\begin{tabular}{|c|c|c|c|c|}
\hline \multirow[t]{2}{*}{ Sample Food } & \multicolumn{4}{|c|}{ Increase / decrease in blood glucose levels in the minute } \\
\hline & 30 & 60 & 90 & 120 \\
\hline Bread & 31 & -1 & 3,8 & $-14,9$ \\
\hline Baboon cake control (K1) & 22,8 & $-1,2$ & $-2,8$ & $-2,5$ \\
\hline Baboon cake (K2) & 19,7 & $-8,7$ & $-3,7$ & $-9,4$ \\
\hline
\end{tabular}

d. Glycemic Index

The results of the average glycemic index of 10 subjects can be seen in Table 6 . Baboon cake substitution of modified sweet potato flour and tempeh flour formula 2 (K2) has a GI of $46.77 \%$, while for control baboon cake has a GI of $61.67 \%$.

Tabel 6. Glycemic Index Baboon Cake

\begin{tabular}{|l|l|l|l|l|}
\hline \multicolumn{1}{|c|}{ Sample Food } & $\begin{array}{l}\text { Area Under Curve } \\
(\mathrm{cm})\end{array}$ & $\begin{array}{l}\text { glycemic } \\
\text { index (\%) }\end{array}$ & Categori * & P-Value \\
\cline { 1 - 2 } Bread & 5881,5 & & 0,028 \\
\hline Baboon cake control (K1) & 3627 & 61,67 & Moderate & 0 \\
\hline Baboon cake (K2) & 2751 & 46,77 & Low & \\
\hline
\end{tabular}

*Independent T-test $95 \%$

Based on the GI value classification, baboon cake (K2) is included in low GI while control baboon cake (K1) is included in medium GI. Foods with low GI will raise blood glucose levels slowly, on the other hand, foods with high GI will increase blood glucose levels quickly. So it is recommended to eat foods with a low GI. The goal is to reduce the glycemic load of food. The results of statistical tests showed that glycemic index the baboon cake (K2) was significantly different from the control baboon cake because the raw materials of the two products are different. The control baboon cake uses raw materials of $100 \%$ tapioca while the baboon cakes (K2) use tapioca raw materials substituted with composite flour with the comparison, namely tapioca: modified red sweet potato flour; tempe flour $=60: 20: 20$. Based on table 1, the data shows that the dietary fiber and resistant starch in the baboon cakes (K2) is higher than the control baboon cakes (K1). The low GI value is thought to be due to the modified sweet potato flour containing relatively high dietary fiber, based on the research of the (Putri and Muliani, 2019) states that the modified red sweet potato flour has a high food fiber content of $44.64 \%$ so it is good if used as a source of dietary fiber to be applied as a food ingredient in the diet.

Modification of red sweet potato flour was carried out by physical method, namely autoclavingretrogradation, resulting in a high content of resistant starch due to the heating-cooling process. According to (Gibson et al., 2010), complex carbohydrates have a smaller glucose response in the blood. The carbohydrates contained in these foods will be broken down slowly so that the release of glucose into the blood runs slowly (The global diabetes community, 2019). Modified sweet potato flour-based foods digest more slowly and increase blood sugar levels slowly. Several factors that influence are levels of dietary fiber, levels of amylose and amylopectin, levels of fat and protein. High dietary fiber contributes to low GI values (Trinidad et al., 2010). The presence of fiber in food can slow digestion of carbohydrates (Hidayat et al., 2017). Fiber forms a matrix outside the starch granules so that it can inhibit the digestion of carbohydrates (Alsaffar, 2011). Fiber can act as a physical barrier to digestion. Fiber can slow down the rate of food in the digestive tract and inhibit enzyme activity so that the digestive process, especially starches, slows down and the blood glucose response is lower. Thus the GI tends to be lower. Food with high fat and protein content tend to have a lower GI than similar foods that are low in fat and protein.

Protein of baboon cake (K2), which is $6.18 \%$, also affects the glycemic index of baboon cakes. This happens because of the addition of composite flour with the ratio, namely tapioca: modified red sweet potato flour; tempeh flour $=60: 20: 20$. According to (Alsaffar, 2011), protein can also form a food matrix outside the starch granules. The presence of this food matrix can inhibit the gelatinization of starch, thereby slowing the digestion of starch. 
Low-GI foods will be digested and converted into glucose gradually, so that the peak blood glucose levels will also be low, this means that the fluctuation of the increase in glucose levels is relatively low. Conversely, high-GI foods will be digested and converted into glucose quickly. GI provides information about the rate at which carbohydrates convert to blood glucose, but does not provide information about the amount of carbohydrates and the impact of certain foods on blood glucose levels.

e. Glycemic Load (GL)

Glycemic Load (GL) is directly proportional to the carbohydrate of food. The classification of food Glycemic Load values is as follows: (1) low GL $(<11),(2)$ moderate GL (11-19), and (3) high GL (> 20). In serving weight $40 \mathrm{~g} \mathrm{GL}$ of control baboon cake (K1) of $12.88 \%$ including medium GL and formula 2 (K2) of 5.21\% is included in low GL. Glycemic load (GL) can provide information about the effect of food consumption on increasing blood glucose levels. Consumption of low-GI foods aims to reduce GL. GL is used to assess the impact of carbohydrate consumption taking into account dietary GI. Table 7 shows that in a sample food $40 \mathrm{~g}$ the glycemic load of the control is 12.88 with the moderate glycemic load category, while the baboon cake (K2) glycemic load is 5.21 with the low glycemic load category.

Table 7. Glycemic Load of Baboon Cake

\begin{tabular}{|l|l|l|l|l|l|}
\hline Sample food & IG & Dose (g) & Carohydrate per Dose (g) & Glycemic Load & Information \\
\hline Baboon cake control (K1) & 61,67 & 40 & 26,37 & 12,88 & Moderate \\
\hline Baboon Cake (K2) & 46,77 & 40 & 21,32 & 5,21 & Low \\
\hline
\end{tabular}

Based on the research results show the value of GL is directly proportional to IG. Foods with a lower GI and GL will trigger a slow rise in blood glucose levels and provides a lower peak blood glucose response so as not to increase the risk of hyperglycemia (Vlachos et al., 2020). Based on the value and classification of the glycemic index and glycemic load, it shows that the formula baboon cake (K2) can be recommended for consumption by people with impaired a glucose tolerance.

\section{Conclusion}

Control baboon cakes (K1) have digestible starch (20,02\%), dietary fiber $(21.58 \%)$ and resistant starch $(13.39 \%)$ with a high category and the baboon cakes (K2) have digestible starch (15,97\%), dietary fiber (37.74\%) and resistant starch (27.94). \%) with a very high category. Digestible starch, resistant starch and dietary fiber has been positively correlated in the prebiotic substitution of modified red sweet potato flour and tempeh flour of control baboon cakes and the (K2) baboon cakes.

The baboon cake glycemic index (K2) was significantly different from the control baboon cake. Control baboon cake has a GI of $61.67 \%$ and a Glycemic load of $12.88 \%$ including the "medium" category and the baboon cake (K2) namely the substitution of modified sweet potato flour and tempeh flour has a GI of $46.77 \%$ and a glycemic load of $5.21 \%$ with the "low" category.

\section{Acknowledgement}

The authors thank to The Tanjungkarang Health Polytechnic, Ministry of Health of The Indonesian Republic for funding this project through with the scemes Higher Education Leading Applied Research (Penelitian Terapan Unggulan Perguruan Tinggi) in 2020 with fund number: HK.02.03/I.2/0588/2020.

\section{References}

Ai, Y. (2013) 'Structures, properties, and digestibility of resistant starch', Graduate Theses and Dissertations, p. 157. Available at: http://lib.dr.iastate.edu/etd/13558.

Alsaffar, A. A. (2011) 'Effect of food processing on the resistant starch content of cereals and cereal products - a review', International Journal of Food Science and Technology, 46(3), pp. 455-462. doi: 10.1111/j.13652621.2010.02529.x.

Aparicio-Saguilán, A. et al. (2007) 'Slowly digestible cookies prepared from resistant starch-rich lintnerized banana starch', Journal of Food Composition and Analysis, 20(3-4), pp. 175-181. doi: 10.1016/j.jfca.2006.07.005.

Badan Pengawasan Obat dan Makanan (2011) Peraturan Kepala Badan Pengawas Obat Dan Makanan Republik Indonesia. Nomor. HK.03.1.23.11.11.09909 Tahun 2011 Tentang Pengawasan Klaim Dalam Label Dan Iklan Pangan Olahan. Indonesian.

Bastian, F. et al. (2013) 'Daya Terima Dan Kandungan Zat Gizi Formula Tepung Tempe Dengan Penambahan Semi Refined Carrageenan ( Src ) Dan Bubuk Kakao', Jurnal Aplikasi Teknologi Pangan, 2(1), pp. 5-8.

Gibson, G. R. et al. (2010) 'Dietary prebiotics: current status and new definition', Food Science \& Technology Bulletin: Functional Foods, 7(1), pp. 1-19. doi: 10.1616/1476-2137.15880.

Goñi, I. et al. (1996) 'Analysis of resistant starch: A method for foods and food products', Food Chemistry, 56(4), pp. 445-449. doi: 10.1016/0308-8146(95)00222-7.

Hidayat, B. et al. (2017) 'Assessment of Corn-Based Rice Analogues Made from Modified Corn Flour and Cassava 
Starch Which Processed by Granulation Method as Functional Food', Food Science and Quality Management, 61(Table 1), pp. 19-24. Available at: www.iiste.org.

Hoerudin (2012) 'Indeks Glikemik Buah Dan Implikasinya Dalam Pengendalian Kadar Glukosa Darah', Buletin Teknologi Pasca Panen, 8(2), pp. 81-98.

Keenan, M. J. et al. (2015) 'Role of resistant starch in improving gut health', Adv. Nutr., 6(2), pp. 198-205. doi: 10.3945/an.114.007419.which.

Kustanti, I. (2017) 'Formulasi Biskuit Rendah Indeks Glikemik (Batik) Dengan Subtitusi Tepung Pisang Klutuk (Musa Balbisiana Colla) Dan Tepung Tempe', Jurnal Aplikasi Teknologi Pangan, 6(1), pp. 12-18. doi: $10.17728 /$ jatp. 217.

Mccleary, B. V. et al (2012) 'Determination of Insoluble, Soluble, and Total Dietary Fiber (CODEX Definition) by Enzymatic-Gravimetric Method and Liquid Chromatography: Collaborative Study', Journal of aoac InternatIonal, 95(3), pp. 824-844. doi: 10.5740/jaoacint.CS2011.

Muchtadi, D., Palupi, N. S. and M, A. (1992) Petunjuk Laboratorium Metode Kimia, Biokimia, dan Biologi dalam Evaluasi Nilai Gizi Pangan Olahan. Edited by IPB. Bogor: Kebudayaan, Departemen Pendidikan dan Tinggi, Direktorat Jenderal Pendidikan Pusat Antar Universitas.

Neyrinck, A. M. et al. (2011) 'Prebiotic effects of wheat Arabinoxylan related to the increase in bifidobacteria, roseburia and bacteroides/prevotella in diet-induced obese mice', PLoS ONE, 6(6). doi: 10.1371/journal.pone.0020944.

Putri, S. and Muliani, U. (2019) Kajian peningkatan pati resisten dengan menggunakan metode autoclaving retrogradation pada berbagai jenis tepung ubi jalar termodifikasi sebagai sumber prebiotic. Laporan Penelitian Terapan Perguruan Tinggi. Poltekkes Tanjungkarang. Bandar Lampung.

The global diabetes community (2019) Carbohydrates and Diabetes, Diabetes Digital Media Ltd. Available at: https://www.diabetes.co.uk/nutrition/carbohydrates-and-diabetes.html.

Trinidad, T. P. et al. (2010) 'Glycemic index of commonly consumed carbohydrate foods in the Philippines', Journal of Functional Foods. Elsevier Ltd, 2(4), pp. 271-274. doi: 10.1016/j.jff.2010.10.002.

Vatanasuchart, N., Niyomwit, B. and Wongkrajang, K. (2012) 'Resistant starch content, in vitro starch digestibility and physico-chemical properties of flour and starch from thai bananas', Maejo International Journal of Science and Technology, 6(2), pp. 259-271. doi: 10.14456/mijst.2012.19.

Vlachos, D. et al. (2020) 'Glycemic index (GI) or glycemic load (GL) and dietary interventions for optimizing postprandial hyperglycemia in patients with T2 diabetes: A review', Nutrients, 12(6). doi: 10.3390/nu12061561. 